\title{
Rapid and Sensitive Detection of Phytophthora sojae in Soil and Infected Soybeans by Species-Specific Polymerase Chain Reaction Assays
}

\author{
Yuanchao Wang, Wenli Zhang, Ying Wang, and Xiaobo Zheng
}

Department of Plant Pathology, Nanjing Agricultural University, Nanjing 210095, People's Republic of China. Accepted for publication 3 July 2006.

\section{ABSTRACT}

Wang, Y., Zhang, W., Wang, Y., and Zheng, X. 2006. Rapid and sensitive detection of Phytophthora sojae in soil and infected soybeans by species-specific polymerase chain reaction assays. Phytopathology 96:1315-1321.

Root and stem rot caused by Phytophthora sojae is one of the most destructive diseases of soybean (Glycine max) worldwide. P. sojae can survive as oospores in soil for many years. In order to develop a rapid and accurate method for the specific detection of $P$. sojae in soil, the internal transcribed spacer (ITS) regions of eight $P$. sojae isolates were amplified using polymerase chain reaction (PCR) with the universal primers DC6 and ITS4. The sequences of PCR products were aligned with published sequences of 50 other Phytophthora species, and a region specific to $P$. sojae was used to design the specific PCR primers, PS1 and PS2. More than 245 isolates representing 25 species of Phytophthora and at least 35

Root and stem rot caused by Phytophthora sojae is currently the most devastating disease of soybean (Glycine max), causing severe losses in soybeans worldwide (10). Areas that receive heavy rain may suffer plant mortality and yield losses of up to $100 \%$ in portions of affected fields. P. sojae was first reported around 1950 in Indiana and Ohio (17), and has since become widespread in many soybean-producing countries in the Americas $(8,26,38)$. In the past few years, the disease has also caused serious soybean losses in northeastern China (29).

$P$. sojae is a homothallic species that produces large numbers of oospores in infected soybean tissues (10). The oospores can survive for many years in the soil after decomposition of the plant tissue (10). Following germination, the oospores produce numerous zoospores that swim through films of water to reach the roots that they subsequently infect, after which the pathogen grows into and among the root cells of the plant, causing serious root rot. Cropping of soybean in the same fields over successive years may increase the potential for damage by this disease (26). Given that increasing amounts of soybeans are being transported to and from different areas and countries, root rot caused by $P$. sojae constitutes a severe threat to worldwide soybean production. The development of a technique for the rapid detection of the pathogen in soybean production fields and in soil carried with transported soybeans will be very important for controlling the dispersion of $P$. sojae and maintaining "Phytophthora-free" soybean production.

Corresponding author: X. Zheng; E-mail address: xbzheng@ @jau.edu.cn

* The $\boldsymbol{e}$-Xtra logo stands for "electronic extra" and indicates that Figure 3 appears in color online.

DOI: 10.1094/PHYTO-96-1315

(C) 2006 The American Phytopathological Society other species of pathogens were used to test the specificity of the primers. PCR amplification with PS primers resulted in the amplification of a product of approximately $330 \mathrm{bp}$, exclusively from isolates of $P$. sojae. Tests with $P$. sojae genomic DNA determined that the sensitivity of the PS primer set is approximately $1 \mathrm{fg}$. This PCR assay, combined with a simple soil screening method developed in this work, allowed the detection of $P$. sojae from soil within $6 \mathrm{~h}$, with a detection sensitivity of two oospores in $20 \mathrm{~g}$ of soil. PCR with the PS primers could also be used to detect $P$. sojae from diseased soybean tissue and residues. Real-time fluorescent quantitative PCR assays were also developed to detect the pathogen directly in soil samples. The PS primer-based PCR assay provides a rapid and sensitive tool for the detection of $P$. sojae in soil and infected soybean tissue.

Additional keywords: disease management, molecular detection.

The diagnosis of Phytophthora root rot is complex, since multiple species of soilborne pathogens infect soybean, including Pythium spp., Fusarium spp., and Rhizoctonia spp., and the symptoms caused by the different pathogens are very similar. Isolation of a pure culture is required for the diagnosis of this Phytophthora disease. The isolation and accurate identification of $P$. sojae are very difficult since this pathogen grows relatively slow. A rapid pathogen detection method and disease diagnostic assay would facilitate pathogen identification and lead to more effective management practices, such as determining the need for fungicide applications to limit disease incidence.

Polymerase chain reaction (PCR) offers advantages over the more traditional methods of pathogen detection and plant disease diagnosis since the organisms need not be cultured prior to detection by PCR and the technique is rapid and sensitive $(2,9,18$, 27,36). In addition, though quantitative real-time PCR is being used increasingly in plant pathology for the accurate detection and quantification of plant pathogens $(1,7,34,35,37)$, its application in the detection and quantification of pathogens from soil samples remains limited $(5,6,11,20,40)$.

The objectives of this study were to develop a rapid and sensitive PCR-based method for the specific amplification of $P$. sojae from the soil carried with transported soybeans or in production fields, and to develop a rapid assay to detect the pathogen in infected soybean tissues. We also described the use of real-time PCR combined with fluorescent SYBR Green I dye to quantify $P$. sojae directly from soil.

\section{MATERIALS AND METHODS}

Source of isolates. $P$. sojae isolates were obtained from diseased soybean stems collected in Heilongjiang and Fujian provinces from 2002 to 2004. By using a leaf disk baiting method (22), 
additional isolates were baited from soybean residues and soil carried with soybeans imported from the United States, Canada, Brazil, and Argentina. The virulence and race type of these isolates have not been tested. Thirteen known races of $P$. sojae were provided by B. Tyler and J. Peng. The $P$. sojae isolates, as well as isolates of Phytophthora spp., Pythium spp., Fusarium spp., and various other pathogens, have been maintained in a collection at Nanjing Agricultural University, Department of Plant Pathology, and are listed in Tables 1 and 2.

Source of soil samples. A total of 118 soil samples were collected from the soybean production fields in Heilongjiang province of China in 2003 and 2004 where the soil type is phaeozem. In addition, 33 soil samples were collected from the soil carried with soybeans imported from the United States, Brazil, Argentina, and Canada. In commercial processing systems, soybeans are typically screened to remove contaminated soil and soybean residues. This soil and residue was collected for PCR assays and the samples evaluated are listed in Table 3.

Extraction of DNA from mycelium. Phytophthora isolates were cultured on tomato juice medium (39) (per liter, $200 \mathrm{ml}$ of tomato juice, $0.1 \mathrm{~g}$ of $\mathrm{CaCO}_{3}$, and $15 \mathrm{~g}$ of agar mixed with sterile distilled water, sterilized at $120^{\circ} \mathrm{C}$ for $20 \mathrm{~min}$ ). Mycelia of each Phytophthora and Pythium isolate were obtained by growing the isolates in tomato juice broth (39) at 18 to $25^{\circ} \mathrm{C}$ (temperaturedependent isolates) for at least 5 days. Mycelia of the other fungi were grown in potato dextrose broth (10). The mycelia were harvested by filtration and frozen at $-20^{\circ} \mathrm{C}$. DNA was extracted from the mycelia according to a modified cetyltrimethylammonium bromide procedure (CTAB) (25). The DNA was dried at room temperature, resuspended in Tris-EDTA (TE) buffer (10 $\mathrm{mM}$ Tris- $\mathrm{HCl}$ and $0.1 \mathrm{mM}$ EDTA, $\mathrm{pH} 8.0$ ), and stored at $-20^{\circ} \mathrm{C}$.

Extraction of DNA from single oospores. Oospore suspensions were prepared and treated with $\mathrm{KMnO}_{4}$ according to the method described by Chang and Ko (3). Single oospores were picked under a microscope and rinsed with $100 \mu \mathrm{l}$ of sterile distilled $\mathrm{H}_{2} \mathrm{O}$ in 1.5-ml Eppendorf tubes and then surface dried with tissue. Fifty microliters of $2 \%$ CTAB was added to the tube. The procedure for DNA extraction was identical to that described previously.

Extraction of $\boldsymbol{P}$. sojae DNA from soil. A screening method was developed to collect oospores from soil collected above. Based on the size of P. sojae oospores, 200-, 300-, and 400-mesh screens of $20 \mathrm{~cm}$ in diameter were used to eliminate most of the soil, and a 600-mesh, 20-cm-diameter screen was used to collect the oospores. In addition, $20 \mathrm{~g}$ of soil was first macerated in $300 \mathrm{ml}$ of water in a $500-\mathrm{ml}$ beaker for $30 \mathrm{~min}$, stirred with a glass rod for $10 \mathrm{~min}$, and then added to a series of screens (200-, $300-$, 400-, and 600-mesh from top to bottom). The screens were rinsed with copious amounts of water, and the material remaining on the 600-mesh screen was collected for DNA extraction and staining of oospores.

DNA was extracted directly from the soil samples according to a method modified from Heinz and Platt (14). Concentrated soil samples were ground to a fine powder in liquid nitrogen with a mortar and pestle, and approximately $0.4 \mathrm{~g}$ of the powder was transferred to a $1.5-\mathrm{ml}$ centrifuge tube. The soil powder was first suspended in $0.5 \mathrm{ml}$ of $0.4 \%$ skim milk powder solution by vigorous vortexing and then centrifuged $(12,000 \times g, 15 \mathrm{~min})$ to remove the soil. The supernatant (approximately $0.4 \mathrm{ml}$ ) was transferred to a centrifuge tube into which $0.4 \mathrm{ml}$ of proteinase $\mathrm{K}$ extraction buffer (50 mM Tris- $\mathrm{HCl}$ [pH 8.0], $25 \mathrm{mM}$ EDTA, $100 \mathrm{mM} \mathrm{NaCl}, 1 \%$ [wt/vol] sodium dodecyl sulfate, and proteinase $\mathrm{K}$ at $10 \mu \mathrm{g} / \mathrm{ml}$ ) had been added, and the sample was incubated for $1 \mathrm{~h}$ at $55^{\circ} \mathrm{C}$. One-half volume $(0.4 \mathrm{ml})$ of $7.5 \mathrm{M}$ ammonium acetate was added to the sample, and the precipitated cell debris was removed by centrifugation at $12,000 \times g$ for $15 \mathrm{~min}$. The nucleic acids in the supernatant were precipitated with
2 volumes of ethanol at $-20^{\circ} \mathrm{C}$ for 30 min or overnight. The DNA was pelleted, rinsed with $70 \%$ ethanol, dried, dissolved in $5 \mu \mathrm{l}$ of sterile water or $0.1 \times \mathrm{TE}$ buffer $(10 \mathrm{mM}$ Tris- $\mathrm{HCl}$ and $1 \mathrm{mM}$ EDTA, $\mathrm{pH}$ 8.0), and used as a template for PCR amplification or stored at $-20^{\circ} \mathrm{C}$ until use.

Discrimination of live and dead oospores. The MTT (3-(4,5dimethylthiazol-2-yl)-2,5-diphenyl-2H-tetrazolium bromide) staining method was used to determine whether the oospores recovered from the soil were alive or dead (30). First, 0.05\% MTT was added to the material gathered from the 600-mesh screen. The sample was incubated for $48 \mathrm{~h}$ at $35^{\circ} \mathrm{C}$ and then observed under a microscope. The oospores that germinated stained blue, and those in dormancy appeared pink, but dead oospores were either stained dark or not stained. Impurities such as pieces of soil remained unstained.

PCR. Each reaction for the DC6/internal transcribed spacer 4 (ITS4) protocol consisted of $2.5 \mu \mathrm{l}$ of $10 \times$ PCR buffer, $1 \mu \mathrm{l}$ of $2.5 \mathrm{mM}$ dNTPs, $2.5 \mu \mathrm{l}$ of $25 \mathrm{mM} \mathrm{MgCl} 2,0.25 \mu \mathrm{l}$ each of $20 \mu \mathrm{M}$ primers, and $0.25 \mu \mathrm{l}$ of $\mathrm{Taq}$ DNA polymerase (5 units/ $\mu \mathrm{l}$ ), to which were added template DNA and finally sterile distilled $\mathrm{H}_{2} \mathrm{O}$ was added to a final volume of $25 \mu \mathrm{l}$. All reactions were performed in a PTC2000 PCR instrument (MJ Research, Watertown, $\mathrm{MA})$. The thermal cycling settings used were an initial denaturation at $94^{\circ} \mathrm{C}$ for $5 \mathrm{~min} ; 35$ cycles of denaturation at $94^{\circ} \mathrm{C}$ for $30 \mathrm{~s}$, annealing at $55^{\circ} \mathrm{C}$ for $30 \mathrm{~s}$ and extension at $72^{\circ} \mathrm{C}$ for $30 \mathrm{~s}$; and a final extension at $72^{\circ} \mathrm{C}$ for $10 \mathrm{~min}$. Negative controls lacking template DNA were performed in each experiment to test for contaminated reagents. All of the reagents used for the PCR amplification were purchased from Promega (Shanghai).

The products amplified from eight isolates of $P$. sojae by the universal primers DC6 and ITS4 (2) were purified according to Sambrook et al. (25) and fused into the pGEM-T Easy Vector (Promega) according to the manufacturer's instructions. Samples of plasmids containing the PCR products were sent to Sanggon in Shanghai for automated DNA sequencing on an ABI Prism System automated sequencer (Model 377, version 2.1.1, PerkinElmer Corp., Foster City, CA). Three clones from each isolate were sequenced. The sequences were aligned with published sequences from 50 other Phytophthora species (4) found in GenBank using ClustalW in BioEdit version 4.8.2 (13). A region specific to $P$. sojae was identified and used to design two PCR primers, PS1 and PS2, which were then synthesized by TaKaRa (Japan). The PCR conditions used with primers PS1 and PS2 were similar to those described above for ITS4 and DC6, except the annealing temperature was $66^{\circ} \mathrm{C}$ and $2.5 \mu \mathrm{l}$ of bovine serum albumin (BSA) $(0.1 \%)$ was added.

Quantitative detection of $P$. sojae in the soil samples. A realtime PCR method was developed to quantitatively detect $P$. sojae in soil. The reactions were carried out in a $50-\mu$ l volume that consisted of $0.5 \mu \mathrm{M}$ of each primer (PS1/PS2); $5 \mu$ of DNA solution extracted from soil samples; a $2.5-\mu \mathrm{l}$ mixture containing $12.5 \mu \mathrm{M}$ each dNTP; $5 \mu$ l of $10 \times$ PCR buffer; $2.5 \mathrm{mM} \mathrm{Mg}^{2+} ; 1.25 \mathrm{U}$ of Taq DNA polymerase (Promega); $2.5 \mu \mathrm{l}$ of $20 \times \mathrm{SYBR}$ Green I (OPE Technology Development Co., Ltd., Shanghai, China); and sterile distilled $\mathrm{H}_{2} \mathrm{O}$ to a final volume of $50 \mu \mathrm{l}$. The thermal cycling settings used were the same as those for the general PCR. Quantitative PCR experiments were performed in an ABI Prism 7000 Sequence Detection System (Perkin-Elmer). A standard curve was first established by plotting the log of a known concentration (10-fold dilution series from $100 \mathrm{fg}$ to $10 \mathrm{ng}$ in reaction volumes of $50 \mu \mathrm{l})$ of DNA from $P$. sojae against the threshold cycle $(\mathrm{Ct})$ values and melting curve. $\mathrm{Ct}$ values resulting from assays of unknown samples were plotted onto this curve, and the inferred concentration of $P$. sojae was calculated. The DNA samples extracted from $20 \mathrm{~g}$ of soil were suspended in $10 \mu \mathrm{l}$ of ultrapure water and used for PCR amplification. The amount of DNA per gram of soil was obtained from the standard curve. The concentrations of DNA were estimated based on six replicates. 
TABLE 1. Isolates of Phytophthora sojae and other fungi used to screen the polymerase chain reaction (PCR)-specific primers (PS1/PS2)

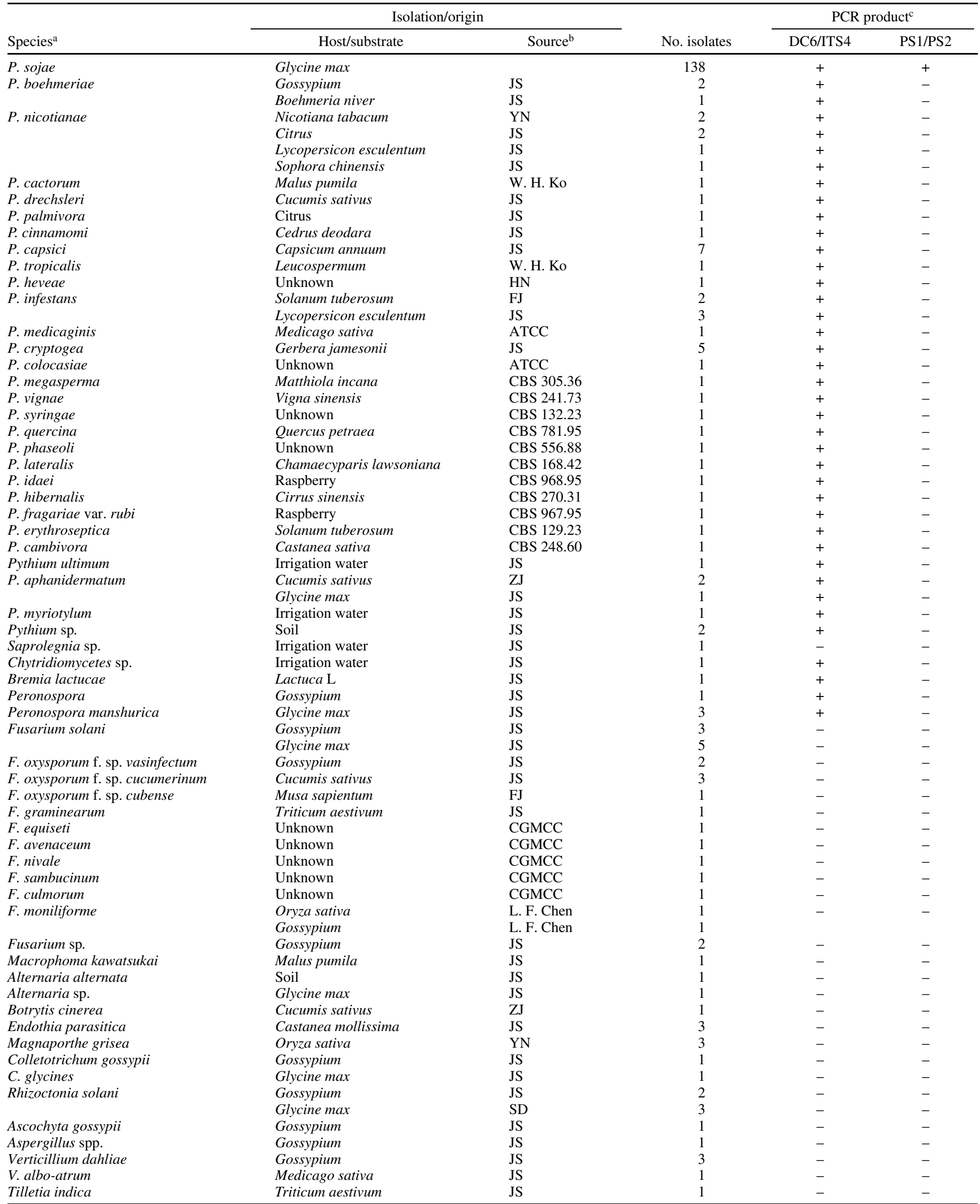

${ }^{a}$ All P. sojae isolates and other Phytophthora species were maintained in the collection of Nanjing Agric. University. All other fungi genera were collected in this study.

${ }^{\mathrm{b}}$ Isolates were isolated from the following sources: JS = Jiangsu province; $\mathrm{SD}=$ Shandong province; YN = Yunnan province; HN = Hainan province; ZJ = Zhejiang province; FJ = Fujian province; HLJ = Heilongjiang province; W. H. Ko from Hawaii University; L. F. Chen from Nanjing Agricultural University; and CGMCC $=$ China General Microbiological Culture Collection Center in Beijing.

c PCR product: + = expected PCR product present; $-=$ no PCR product band. 
Specificity and sensitivity of primers PS1 and PS2. A total of 245 isolates representing 25 species of Phytophthora and 35 species of other pathogens (Tables 1 and 2) were used to determine the specificity of primers PS1 and PS2. Purified DNA and crude DNA extracted from zoospores or oospores of $P$. sojae were used for this purpose. The concentration of the purified $P$. sojae DNA was determined with a spectrophotometer (Beckman DU640; Beckman Coulter Inc., Fullerton, CA), and then a dilution series of the DNA, from $1.0 \mu \mathrm{g}$ to $1 \mathrm{fg}$ of DNA, was used to test the sensitivity of the detection procedure. To extract crude DNA from zoospores, 60 zoospores were suspended in $60 \mu \mathrm{l}$ of double-distilled $\mathrm{H}_{2} \mathrm{O}, 0.5 \mathrm{~g}$ of silica was added, and the mixture was vortexed for $1 \mathrm{~min}$, after which

TABLE 2. Isolates of Phytophthora sojae used to screen the polymerase chain reaction (PCR)-specific primers (PS1/PS2)

\begin{tabular}{|c|c|c|c|c|c|c|}
\hline \multirow[b]{2}{*}{ Isolate $^{\mathrm{a}}$} & \multicolumn{2}{|c|}{ Isolation/origin } & \multirow{2}{*}{$\begin{array}{l}\text { No. of } \\
\text { isolates }\end{array}$} & \multirow[b]{2}{*}{ Races } & \multicolumn{2}{|c|}{ PCR product ${ }^{\mathrm{c}}$} \\
\hline & Host & Source $^{b}$ & & & DC6/ITS4 & PS1/PS2 \\
\hline & Glycine $\max$ & HLJ & 68 & Unknown & + & $+(68 / 68)$ \\
\hline & Glycine $\max$ & FJ & 28 & Unknown & + & + \\
\hline & Glycine $\max$ & USA & 26 & Unknown & + & + \\
\hline & Glycine $\max$ & Brazil & 2 & Unknown & + & + \\
\hline & Glycine max & Argentina & 1 & Unknown & + & + \\
\hline P6497 & Glycine $\max$ & B. Tyler & 1 & 2 & + & + \\
\hline P7064 & Glycine $\max$ & B. Tyler & 1 & 7 & + & + \\
\hline P7074 & Glycine $\max$ & B. Tyler & 1 & 17 & + & + \\
\hline P7076 & Glycine $\max$ & B. Tyler & 1 & 19 & + & + \\
\hline R4 & Glycine $\max$ & J. H. Peng & 1 & 4 & + & + \\
\hline R5 & Glycine $\max$ & J. H. Peng & 1 & 5 & + & + \\
\hline R7 & Glycine $\max$ & J. H. Peng & 1 & 7 & + & + \\
\hline R8 & Glycine $\max$ & J. H. Peng & 1 & 8 & + & + \\
\hline R13 & Glycine $\max$ & J. H. Peng & 1 & 13 & + & + \\
\hline $\mathrm{R} 17$ & Glycine $\max$ & J. H. Peng & 1 & 17 & + & + \\
\hline $\mathrm{R} 18$ & Glycine $\max$ & J. H. Peng & 1 & 18 & + & + \\
\hline R19 & Glycine $\max$ & J. H. Peng & 1 & 19 & + & + \\
\hline R31 & Glycine max & J. H. Peng & 1 & 31 & + & + \\
\hline
\end{tabular}

a All isolates of Phytophthora sojae were maintained in the collection of Nanjing Agric. University.

${ }^{\mathrm{b}}$ Isolates were isolated from the following sources: FJ = Fujian province; HLJ = Heilongjiang province; B. Tyler from Virginia Polytechnic Institute and State University; and J. H. Peng from Dalin Quarantine Bureau of China.

c PCR product: + = expected PCR product present; - = no PCR product band.

TABLE 3. Soil samples used for polymerase chain reaction (PCR) assay

\begin{tabular}{lcccc}
\hline Sources & Soil type & $\begin{array}{c}\text { No. of soil } \\
\text { samples }\end{array}$ & $\begin{array}{c}\text { No. of PCR } \\
\text { positive }\end{array}$ & $\begin{array}{c}\text { No. of leaf disk } \\
\text { baiting positive }^{\mathrm{b}}\end{array}$ \\
\hline Heilongjiang & Phaeozem & 118 & 67 & 46 \\
United States & Unknown & 24 & 19 & 12 \\
Canada & Unknown & 6 & 4 & 3 \\
Brazil & Unknown & 2 & 1 & 1 \\
Argentina & Unknown & 1 & 1 & 1 \\
Total & & 151 & 92 & 63
\end{tabular}

a Number of soil samples that gave positive signals by PCR assay.

${ }^{b}$ Number of soil samples that gave positive signals by leaf disk baiting assay.
$0.5,1,2,3$, to $9 \mu \mathrm{l}$ of suspension solution was added to the PCR reactions. The amplified products were electrophoresed on $1 \%$ agarose gels containing ethidium bromide $(0.5 \mu \mathrm{g} / \mathrm{ml})$, which were run in $1 \times$ Tris-acetate-EDTA running buffer. A 100-bp DNA ladder (TaKaRa, Japan) was included on each gel as a molecular size standard. The experiments were repeated at least three times.

PCR amplification from diseased plant tissue. $P$. sojae-infected soybean tissues were collected from Heilongjiang province in 2003, and DNA was prepared from the diseased tissues by an $\mathrm{NaOH}$ lysis method for PCR, according to Wang et al. (33). Healthy soybean root tissue was used as a negative control. One microliter of this extract was used as the DNA template. The PCR conditions used were identical to those described above for amplification with the PS primers. The PCR amplifications were repeated at least three times per sample. In addition, to confirm that no PCR inhibitors were present in healthy soybean tissues, the primers ITS1 and ITS4, which amplify the ITS region of soybean, were used in PCR analyses as a positive control.

\section{RESULTS}

Sequence analysis. The sequences from the ITS regions of all eight $P$. sojae isolates from different sources were more than $99.5 \%$ identical. These sequences were aligned with previously published sequences from a corresponding region of the genomes of 50 other Phytophthora spp., including $P$. sojae, $P$. drechsleri, $P$. medicaginis, and $P$. megasperma. The variable sequences in the ITS1 and ITS2 regions were identified and used to design a pair of potential $P$. sojae-specific primers, PS1 (5'-CTGGATCATGAGCCCACT-3') and PS2 (5' - GCAGCCCGAAGGCCAC$\left.3^{\prime}\right)$. The entire ITS sequence from $P$. sojae isolate $\mathrm{S} 317$ was submitted to GenBank (accession no. AY742749).

Specificity. From all of the oomycete isolates, including Phytophthora spp., Pythium spp., and Peronospora spp., an approximate $1.3-\mathrm{kb}$ product was amplified with primers DC6 and ITS4, with the exception of Saprolegnia sp., only one fungi isolate, Chytridiomycetes sp., yielded a product with the same size (Table 1). However, 138 isolates representing $P$. sojae exclusively yielded a product of approximately $330 \mathrm{bp}$ (Tables 1 and 2; Fig. 1) with primers PS1 and PS2. Isolates representing all of the other Phytophthora species and the other genera tested yielded no amplification product with primers PS1 and PS2. However, when the annealing temperature decreased to less than $65^{\circ} \mathrm{C}$, a specific 330-bp PCR product could be amplified from $P$. drechsleri (data not shown).

Sensitivity. PCR with primers PS1 and PS2 yielded positive results with 10 concentrations of purified DNA as the template, from $1 \mu \mathrm{g}$ to $1 \mathrm{fg}$ (Fig. 2A). In reactions containing crude DNA from zoospores, the DNA from 0.5 to $9 \mu$ of zoospore DNA extract (60 zoospores) all allowed the amplification of the 330-bp DNA band (Fig. 2B). The DNA extracted from a single oospore was also sufficient for PCR detection (Fig. 2C).

Recovery of oospores from soil residues carried by soybeans. Twenty grams of soil was sieved by a series of screens and

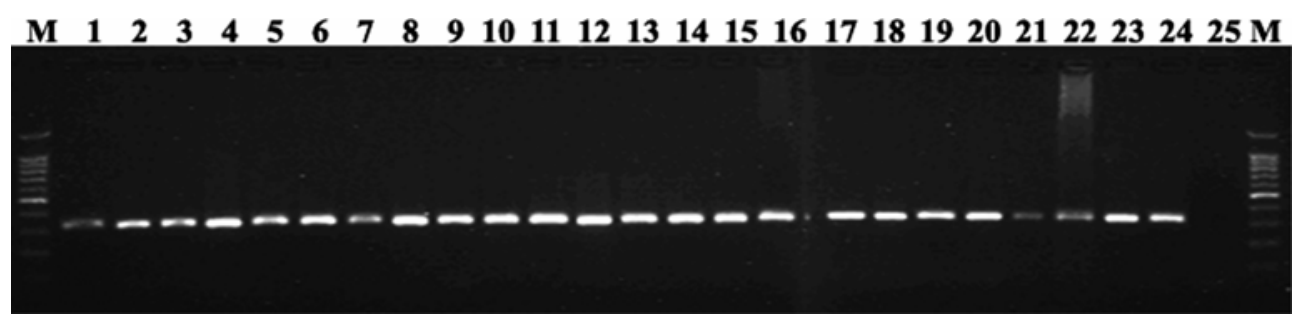

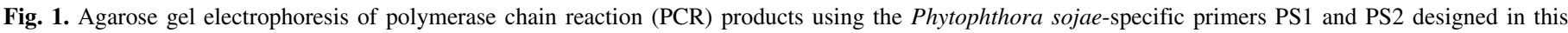

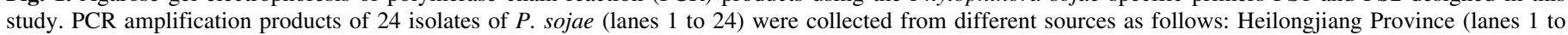
12), United States (lanes 13 to 19), Brazil (lanes 20 to 22), Canada (lane 23), and Argentina (lane 24). Lane 25, no template DNA; M, 100-bp DNA ladder. 
the oospores residing in $20 \mathrm{~g}$ of soil were collected into a soil sample of approximately $0.4 \mathrm{~g}$ per soil sample. The MTT staining method demonstrated that most of the oospores recovered from the soil were viable (Fig. 3). The DNA extracted from the concentrated soil samples was used for PCR amplification and produced a 330-bp band. In an artificial experiment, when only two oospores are present in $20 \mathrm{~g}$ of soil sample (soil type is phaeozem), all samples are PCR positive. This experiment was repeated more than 10 times with similar results.

The newly designed protocol described here was extensively applied on samples collected from quarantine bureaus of China. From 2004 to 2005, 33 soil samples collected from soybeans imported from the United States, Canada, Brazil, and Argentina were subjected to PCR assay, and 25 samples gave positive signals (Table 3; Fig. 4). Seventeen samples were further confirmed by the leaf disk baiting method, indicating the presence of the pathogen. This technique was also applied to 118 soil samples collected from the soybean production areas of Heilongjiang province from 2003 to 2004 and 67 of the samples gave positive signals, 46 of which were further confirmed by the leaf baiting method (Table 3 ). In addition, all soil samples positive in the leaf disk baiting method were confirmed by PCR.

PCR amplification from diseased plant tissue. After the preparation of template from the blighted soybean tissue by $\mathrm{NaOH}$ extraction followed by PCR amplification using primers PS1 and PS2, a single PCR product of approximately $330 \mathrm{bp}$ was detected (Fig. 5). The presence of $P$. sojae in the diseased plants was confirmed by isolating the pathogen from the tissue to a pure culture. In contrast, no PCR product was amplified from healthy soybean tissues. Amplification carried out using the ITS universal
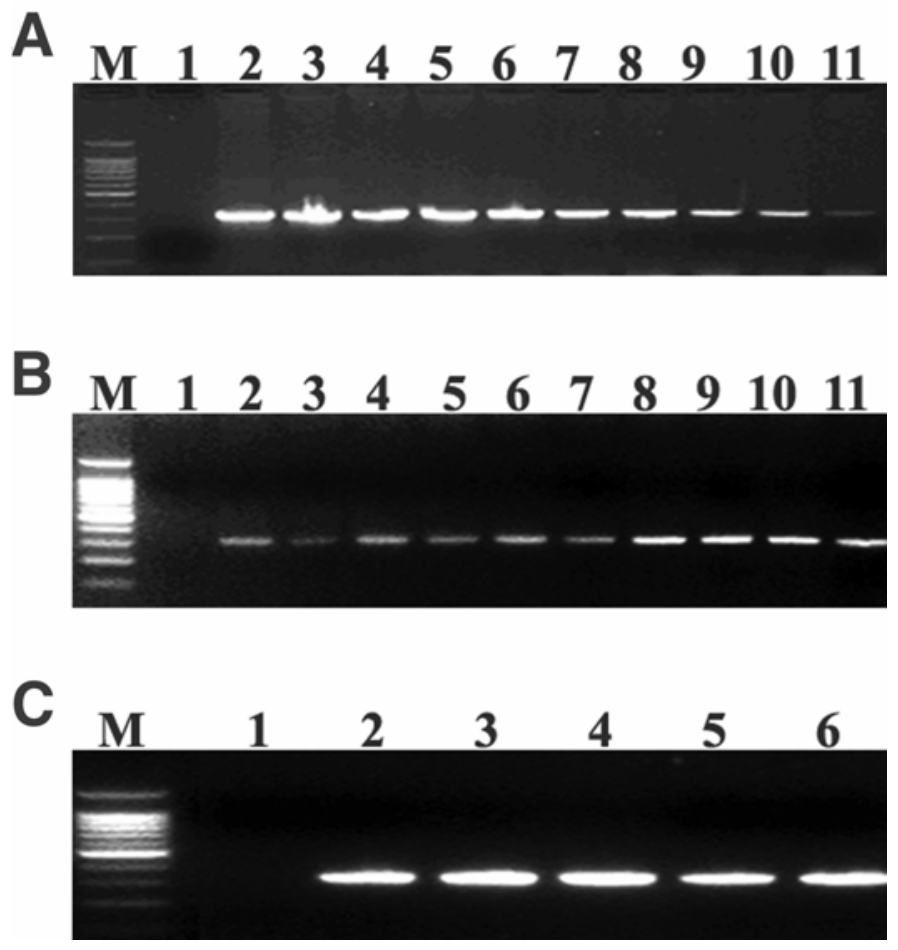

Fig. 2. Sensitivity of molecular detection using the Phytophthora sojaespecific primers PS1 and PS2 designed in this study. A, The purified DNA was used as template. No template DNA (lane 1). Lanes 2 to 11 were purified genomic DNA from $1 \mu \mathrm{g}, 100 \mathrm{ng}, 10 \mathrm{ng}, 1 \mathrm{ng}, 100 \mathrm{pg}, 10 \mathrm{pg}, 1 \mathrm{pg}, 100 \mathrm{fg}$, $10 \mathrm{fg}$, and $1 \mathrm{fg}$, respectively. M, 100-bp DNA ladder. B, Crude DNA from zoospores was used as template (60 zoospores were extracted to produce $60 \mu \mathrm{l}$ of extract). No template DNA (lane 1). Lanes 2 to 11 were crude DNA extracted from zoospores using $0.5,1,2,3,4,5,6,7,8$, and $9 \mu \mathrm{l}$, respectively. M, 100-bp DNA ladder. C, DNA from a single oospore was used as template. No template DNA (lane 1). Lanes 2 to 6 used DNA from a single oospore. M, 100-bp DNA ladder. primer produced a 700-bp DNA band from healthy soybean tissue indicating the absence of PCR inhibitors in the healthy extract.

Quantitative detection of $\boldsymbol{P}$. sojae in the soil samples. DNA extracted from two field soil samples collected in diseased soybean fields in Heilongjiang province and one other soil sample collected from imported U.S. soybeans were subjected to realtime fluorescent quantitative PCR using primers PS1 and PS2 (Fig. 6). The amount of DNA in each soil sample is shown in Table 4.

\section{DISCUSSION}

One objective of this work was to develop PCR primers for the rapid and specific amplification of $P$. sojae in the soil contaminating transported soybeans, infested soil in production fields, and diseased soybean tissues. PCR with primers PS1 and PS2 amplified a product of approximately $330 \mathrm{bp}$ exclusively from all isolates of $P$. sojae. A simple mesh screen method to concentrate oospores from soil combined with the PCR assay allowed the detection of $P$. sojae from soil within $6 \mathrm{~h}$. In addition, a quantitative real-time PCR was also developed to quantify $P$. sojae directly from soil. The PS primers were also able to be used to detect $P$. sojae in infected soybean tissues.
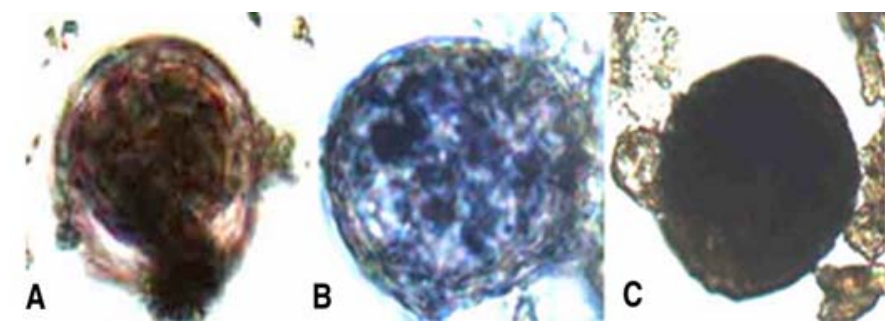

Fig. 3. MTT (3-(4,5-dimethylthiazol-2-yl)-2,5-diphenyl-2H-tetrazolium bromide) staining of oospores recovered from the soil by the screen method. A, dormant oospore; $\mathbf{B}$, germinating oospore; and $\mathbf{C}$, dead oospore.

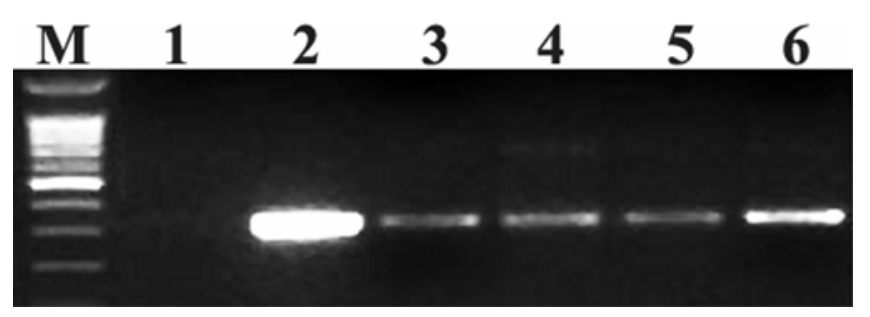

Fig. 4. PS primers amplification of Phytophthora sojae from the soil carried with the imported soybeans. Lane 1, no template DNA; lane 2, $100 \mathrm{pg}$ of purified DNA of $P$. sojae; lanes 3 to 6, soil samples from different sources (United States [lanes 3 and 4], Brazil [lane 5], and Canada [lane 6]); and M, 100-bp DNA ladder.

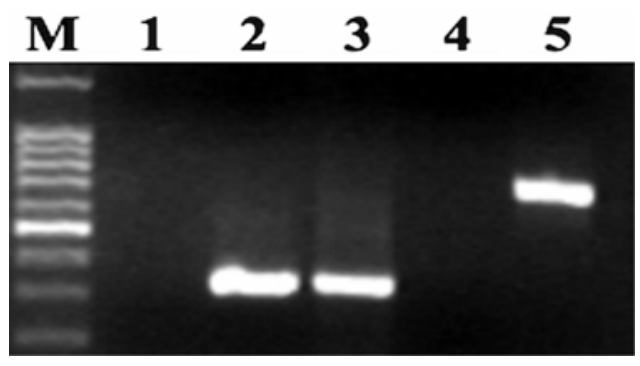

Fig. 5. PS primers amplification of Phytophthora sojae from infected soybean tissues. Lane 1, no template DNA; lane 2, 100 pg of purified DNA of $P$. sojae; lane 3, DNA from infected soybean tissue; lane 4, DNA from healthy soybean tissue; lane 5, amplification of approximately 700-bp product from healthy soybean tissue with the universal primer set internal transcribed spacer 1 (ITS1)/ITS4; and M, 100-bp DNA ladder. 
Sensitivity and specificity are very important for the detection of pathogens. The molecular detection sensitivity of one $P$. nicotianae assay is between 80 and $800 \mathrm{fg}$ of DNA/ $\mu \mathrm{l}(18)$, and another technique to detect $P$. boehmeriae has a detection sensitivity of approximately 10 to $100 \mathrm{fg}$ (27). However, the PS primers provide a more sensitive technique for the detection of $P$. sojae, with only $1 \mathrm{fg}$ of purified DNA required to detect the pathogen. Regarding the specificity, more than 245 isolates representing 25 species of Phytophthora and at least 35 other species of pathogens, many potentially associated with soybeans, did not generate a product with the PS primers, with one possible exception. The sequences of the PS primers vary from $P$. drechsleri sequences at only one nucleotide requiring the need to increase the annealing temperature to $66^{\circ} \mathrm{C}$. P. drechsleri has a wide host range including various vegetable crops, lucerne, and a wide range of ornamentals and trees (28). However, this species does not infect soybeans (15) and is not likely to occur at detectable levels in soybean fields or soybean residue. False negatives could be avoided using the higher annealing temperature, through future work to develop more specific primers, or development of other techniques such as enzyme digestion and nested-PCR. In our assays, $P$. drechsleri was not encountered when isolates were obtained using the leaf baiting assay and culturing of the Phytophthora pathogens present.

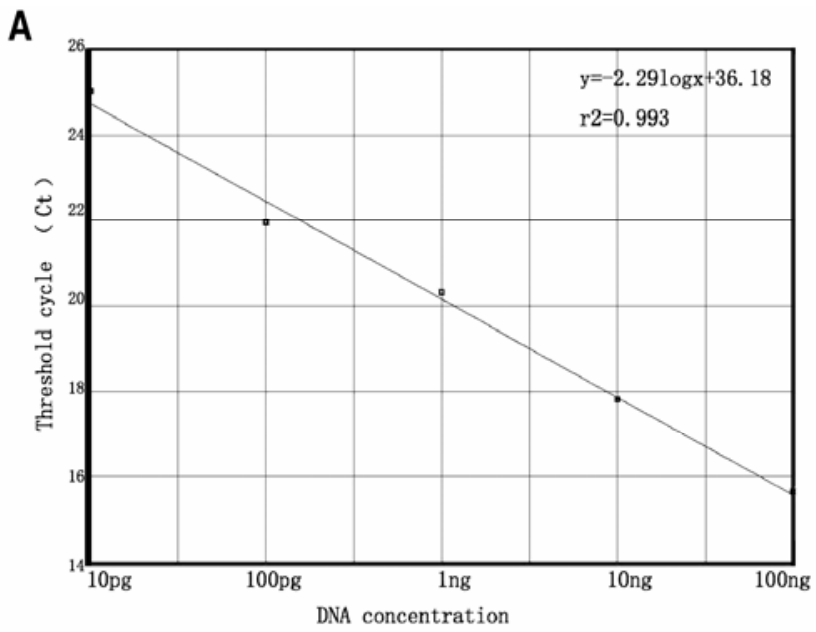

B

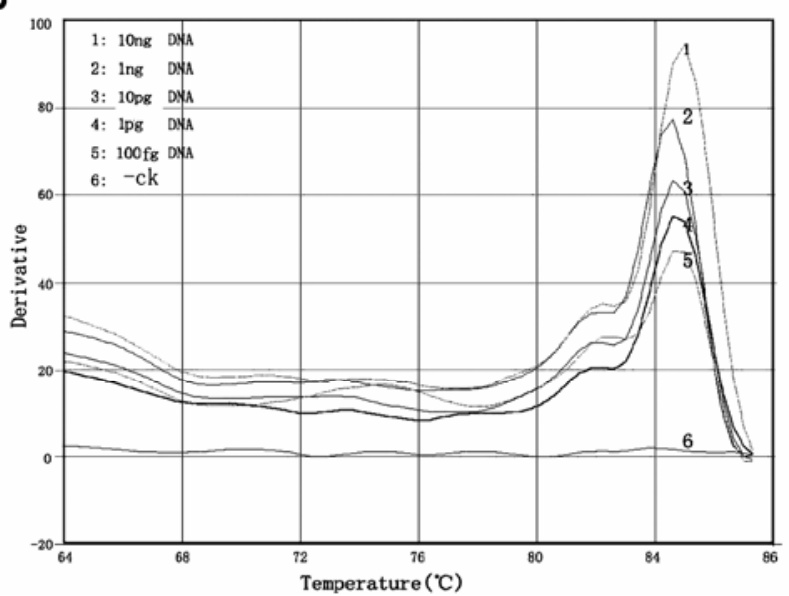

Fig. 6. A, Standard curve obtained by plotting the log of a known DNA concentration of Phytophthora sojae (10 pg to $100 \mathrm{ng}$ ) against the threshold cycle (Ct) values obtained from real-time quantitative polymerase chain reaction (PCR) assays. B, Melting curve profile for real-time PCR amplification of $P$. sojae pure genomic DNA. The negative derivative of fluorescence with respect to temperature is plotted as $\mathrm{dF} / \mathrm{dT}$ versus temperature to obtain a graphical representation of the melting peaks.
The PCR assay allows the rapid detection of the pathogen in soil. Although $P$. sojae is a quarantine pathogen in China, more than 20 million tons of soybeans are imported into China annually. In addition, because most of the soybeans used as seeds in China are transported from Heilongjiang province, where $P$. sojae has been isolated, rapid determination of whether $P$. sojae exists in the soil carried with the transported soybeans is not only important for the soybean trade between China and other countries, but also for controlling the spread of $P$. sojae within China. The PS primer-based PCR assay requires only $6 \mathrm{~h}$ for the detection of $P$. sojae in soil. Compared with the extensively used soybean leaf disk baiting method which needs at least 15 to 20 days for pathogen detection (22), the newly designed PCR assay provides a much more efficient method, which has been extensively applied in some quarantine bureaus of China during the past several years. Given its speed and efficiency, the PCR method is specially fit as a tool in quarantine measures.

The thick-walled oospores of $P$. sojae may remain dormant and persist in soybean residues and soil for many years in the fields (10). Sensitive detection of the pathogen from soil will lead to more effective disease management practices. However, the quantity of oospores in soil is limited and the extraction of target DNA directly from soil is difficult. To concentrate the soilborne oospores before DNA extraction, a method to collect oospores through a series of screens was developed, by means of which all of the oospores in $20 \mathrm{~g}$ of soil could be collected in a final $0.4-\mathrm{g}$ volume of soil. The screening procedure, combined with the PCR assay, allowed the detection of as few as two oospores in a 20 -g soil sample. This procedure constitutes a very efficient method for the detection of $P$. sojae from the soil directly. To our knowledge, this is the first report of a method to recover P. sojae oospores from soil, and most oospores were demonstrated to be viable by the MTT staining method.

Many PCR-based molecular tools have been developed to detect Phytophthora species and diagnose associated diseases over the past several years $(9,12,18,19,21,23,24,27)$. Recently, Judelson and Tooley (16), Tooley et al. (31), and Trout et al. (32) reported the development of PCR primers to detect $P$. infestans from infected potato. Kong et al. (18) developed PCR primers to detect $P$. nicotianae in irrigation water. To our knowledge, there has been no previous report of the molecular detection of $P$. sojae. In general, Phytophthora spp. are difficult to isolate into pure culture, and baiting and culturing processes are time-consuming. The technique described here circumvents these traditional protocols. To detect $P$. sojae in infected soybean tissues, we adopted a quick lysis assay for infected plant material that eliminates the need for time-consuming extraction of pathogen DNA prior to PCR (33). These techniques should allow the rapid, accurate detection of $P$. sojae from soil and infected plants.

Although this is the first report about the molecular detection of $P$. sojae, which has been used extensively in China during the past several years (Table 3), there are still some limitations in the application of this protocol to monitor $P$. sojae in soybean production fields. Issues associated with spatial distribution of inoculum would require multiple soil samples to be evaluated, and the soil sieving by screens could result in the cross contamination among different soil samples. In general, in such cases, the leaf baiting

TABLE 4. Results of quantitative polymerase chain reaction assay

\begin{tabular}{lccc}
\hline Samples $^{\mathrm{a}}$ & HLJ1 & HLJ2 & US1 \\
\hline Amount $^{\mathrm{b}}$ & $3.29 \pm 1.50 \mathrm{fg}$ & $16.13 \pm 9.59 \mathrm{fg}$ & $54.86 \pm 22.27 \mathrm{fg}$ \\
\hline
\end{tabular}

${ }^{a}$ HLJ1 and HLJ2 represent the soil samples collected from Huanan County and Jiamusi city of Heilongjiang province, respectively. US1 represents a soil sample collected from soybeans imported from the United States in 2004.

b The amount of DNA per gram of soil, the concentrations of DNA were estimated after six replicates. 
method was applied first, and after the water-soaked lesion appeared, the leaf disk was subjected to PCR detection.

Though there are still some limitations to the PCR assay reported here, the sensitivity, specificity, efficiency, and speed make the PCR assay a highly useful technique for detecting $P$. sojae from the soil carried with transported soybeans. Because this PCR assay also has significant practical applications in the detection of $P$. sojae in infected soybean tissues and infested field soils, it constitutes a powerful tool for controlling the dispersion of $P$. sojae and developing disease control strategies.

\section{ACKNOWLEDGMENTS}

This research was supported by the National "973" Program (2002CB111400), Chinese National Science Foundation Committee project (30471124), and New Century Excellent Scholar Program of the Ministry of Education of China (NCET-04-0503). We thank W. H. Ko from Hawaii University, B. Tyler from Virginia Polytechnic Institute and State University, and J. H. Peng from Dalian quarantine bureau and L. F. Chen from Nanjing Agricultural University for providing us with isolates of Phytophthora spp. and other pathogens.

\section{LITERATURE CITED}

1. Bates, J. A., Taylor, E. J. A., Kenyon, D. M., and Thomas, J. E. 2001. The application of real-time PCR to the identification, detection and quantification of Pyrenophora species in barley seed. Mol. Plant Pathol. 2:4957.

2. Bonants, P., Weerdt, M. H. D., Marga, V. G. P. L. I., Cooke, D. E. L., and Duncan, J. M. 1997. Detection and identification of Phytophthora fragariae Hickman by the polymerase chain reaction. Eur. J. Plant Pathol. 103:345-355.

3. Chang, T. T., and Ko, W. H. 1991. Factors affecting the germination of oospores of Phytophthora infestans. J. Phytopathol. 133:29-35.

4. Cooke, D. E. L., Drenth, A., Duncan, J. M., Wagels, G., and Brasier, C. M. 2000. A molecular phylogeny of Phytophthora and related oomycetes. Fungal Genet. Biol. 30:17-32.

5. Cullen, D. W., Lees, A. K., Toth, I. K., and Duncan, J. M. 2001. Conventional PCR and real-time quantitative PCR detection of Helminthosporium solani in soil and on potato tubers. Eur. J. Plant Pathol. 107:387398.

6. Cullen, D. W., Lees, A. K., Toth, I. K., and Duncan, J. M. 2002. Detection of Colletotrichum coccodes from soil and potato tubers by conventional and quantitative real-time PCR. Plant Pathol. 51:281-292.

7. Do Schena, L., Nigro, F., Ippolito, A., and Gallitelli, D. 2004. Real-time quantitative PCR: A new technology to detect and study phytopathogenic and antagonistic fungi. Eur. J. Plant Pathol. 110:893-908.

8. Doupnik, B. J. 1993. Soybean production and disease loss estimates for north central United States from 1989 to 1991. Plant Dis. 77:1170-1171.

9. Ersek, T., Schoelz, J. E., and English, J. T. 1994. PCR amplification of species-specific DNA sequences can distinguish among Phytophthora species. Appl. Environ. Microbiol. 60:2616-2621.

10. Erwin, D. C., and Ribeiro, O. K. 1996. Phytophthora Disease Worldwide. The American Phytopathological Society, St. Paul, MN.

11. Filion, M., St-Arnaud, M., and Jabaji-Hare, S. H. 2003. Direct quantification of fungal DNA from soil substrate using real-time PCR. J. Microbiol. Methods 53:67-76.

12. Fraser, D. E., Shoemaker, P. B., and Ristaino, J. B. 1999. Characterization of isolates of Phytophthora infestans from tomato and potato in North Carolina from 1993 to 1995. Plant Dis. 83:633-638.

13. Hall, T. A. 1999. BioEdit: A user-friendly biological sequence alignment editor and analysis program for Windows 95/98/NT. Nucleic Acids Symp. Series 41:95-98.

14. Heinz, R. A., and Platt, H. W. 2000. Improved DNA extraction method for Verticillium detection and quantification in large-scale studies using PCR-based techniques. Can. J. Plant Pathol. 22:117-121.

15. Irwin, J. A. G., and Dale, J. L. 1982. Relationships between Phytophthora megasperma isolates from chick pea, lucerne and soybean. Aust. J. Bot. 30:199-210.

16. Judelson, H. S., and Tooley, P. W. 2000. Enhanced PCR methods for de- tection and quantification of Phytophthora infestans in plants. Phytopathology 90:1112-1115.

17. Kaufmann, M. J., and Gerdemann, J. W. 1958. Root and stem rot of soybeans caused by Phytophthora sojae n. sp. Phytopathology 48:201-208.

18. Kong, P., Hong, C. X., Jeffers, S. N., and Richardson, P. A. 2003. A species-specific polymerase chain reaction assay for rapid detection of Phytophthora nicotianae in irrigation water. Phytopathology 93:822-831.

19. Lee, S. B., White, T. J., and Taylor, J. W. 1993. Detection of Phytophthora species by oligonucleotide hybridization to amplified ribosomal DNA spacers. Phytopathology 83:177-181.

20. Lees, A. K., Cullen, D. W., Sullivan, L., and Nicolson, M. J. 2002. Development of conventional and quantitative real-time PCR assays for the detection and identification of Rhizoctonia solani AG-3 in potato and soil. Plant Pathol. 51:293-302.

21. Panabieres, F., Marais, A., Trentin, F., Bonnet, P., and Ricci, P. 1989. Repetitive DNA polymorphism analysis as a tool for identifying Phytophthora species. Phytopathology 79:1105-1109.

22. Peng, J. H., and Anderson, T. 1998. Detection of Phytophthora sojae from soil with a soybean leaf-disc baiting method. Plant Quarantine 12:198-203.

23. Ristaino, J. B., Groves, C. T., and Parra, G. 2001. PCR amplification of the Irish potato famine pathogen from historic specimens. Nature 411: 695-697.

24. Ristaino, J. B., Madritch, M., Trout, C. L., and Parra, G. 1998. PCR amplification of ribosomal DNA for species identification in the plant pathogen genus Phytophthora. Appl. Environ. Microbiol. 64:948-954.

25. Sambrook, J., Fritsch, E. F., and Maniatis, T. 1989. Molecular Cloning: A Laboratory Manual. 2nd ed. Cold Spring Harbor Laboratory, Cold Spring Harbor, NY.

26. Schmitthenner, A. F. 1985. Problems and progress in control of Phytophthora root rot of soybean. Plant Dis. 69:362-368.

27. Shen, G., Wang, Y. C., Zhang, W. L., and Zheng, X. B. 2005. Development of a PCR assay for the molecular detection of Phytophthora boehmeriae in infected cotton. J. Phytopathol. 153:291-296.

28. Stamps, D. J. 1985. Phytophthora drechsleri. No. 840 in: Descriptions of Pathogenic Fungi and Bacteria. Commonw. Mycol. Inst., Kew, England.

29. Su, Y. C., and Shen, C. Y. 1993. The discovery and biological characteristic studies of Phytophthora megasperma f. sp. glycinea on soybean in China. Acta Phytopathol. Sin. 23:341-347.

30. Sutherland, E. D., and Cohen, S. D. 1983, Evaluation of tetrazolium bromide as a vital stain for fungal oospores. Phytopathology 73:15321535.

31. Tooley, P. W., Bunyard, B. A., Carras, M. M., and Hatziloukas, E. 1997. Development of PCR primers from internal transcribed spacer region 2 for detection of Phytophthora species infecting potatoes. Appl. Environ. Microbiol. 63:1467-1475.

32. Trout, C. L., Ristaino, J. B., Madritch, M., and Wangsomboondee, T. 1997. Rapid detection of Phytophthora infestans in late blight-infected potato and tomato using PCR. Plant Dis. 81:1042-1048.

33. Wang, H., Qi, M., and Cutler, A. J. 1993. A simple method of preparing plant samples for PCR. Nucleic Acids Res. 21:4153-4154.

34. Ward, L. I., Beales, P. A., Barnes, A. V., and Lane, C. R. 2004. A realtime PCR assay based method for routine diagnosis of Spongospora subterranean on potato tubers. J. Phytopathol. 152:633-638.

35. Weller, S. A., Elphinstone, J. G., Smith, N. C., Boonham, N., and Stead, D. E. 2000. Detection of Ralstonia solanacearum strains with a quantitative, multiplex, real-time, fluorogenic PCR (Taq-Man) assay. Appl. Environ. Microbiol. 66:2853-2858.

36. White, T. J., Bruns, T., Lee, S. B., and Taylor, J. 1990. Amplification and direct sequencing of fungal ribosomal RNA genes for phylogenetics. Pages 315-322 in: PCR Protocols. M. A. Innis, D. H. Gelfand, J. J. Sninsky, and T. J. White, eds. Academic Press, San Diego.

37. Winton, L. M., Stone, J. K., Watrud, L. S., and Hansen, E. M. 2002. Simultaneous one tube quantification of host and pathogen DNA with real-time polymerase chain reaction. Phytopathology 92:112-116.

38. Wrather, J. A., Chambers, A. Y., Fox, J. A., Moore, W. F., and Sciumbato, G. L. 1995. Soybean disease loss estimates for the southern United States, 1974 to 1994. Plant Dis. 79:1076-1079.

39. Zheng, X. B. 1995. Methods in Phytophthora. Chinese Agriculture Press, Beijing.

40. Zhang, Z. G., Zhang, J. Y., Wang, Y. C., and Zheng, X. B. 2005, Molecular detection of Fusarium oxysporum f. sp. niveum and Mycosphaerella melonis in infected plant tissues and soil. FEMS Microbiol. Lett. 249:39-47. 